\title{
INTERACTIONS BETWEEN THE ENDOGENOUS CANNABINOID SYSTEM AND THE PEPTIDES OF THE TYR-MIF-1 FAMILY MODULATE HEAT STRESS-INDUCED ANALGESIA
}

\author{
Hristina H. Nocheva ${ }^{1}$, Roman E. Tashev ${ }^{1}$, Adriana I. Bocheva ${ }^{2}$, Dimitrinka Y. Atanasova ${ }^{3,4}$ \\ Angel D. Dandov ${ }^{5}$, and Nikolai E. Lazarov ${ }^{3,5}$ \\ ${ }^{1}$ Department of Pathophysiology, Medical University, Sofia, Bulgaria \\ ${ }^{2}$ Department of Physiology and Pathophysiology, Medical University, Pleven, Bulgaria \\ ${ }^{3}$ Institute of Neurobiology, Bulgarian Academy of Sciences, Sofia, Bulgaria \\ ${ }^{4}$ Department of Anatomy, Faculty of Medicine, Trakia University, Stara Zagora, Bulgaria \\ ${ }^{5}$ Department of Anatomy and Histology, Medical University, Sofia, Bulgaria
}

The present study aimed at evaluating whether an interaction between the endocannabinoid system (ECS) and peptides from the Tyr-MIF-1 family modulates heat stress-induced analgesia. For this purpose, adult male rats were subjected to 1 hour of heat stress. Pain perception was estimated in vivo by Paw pressure test. Immunohistochemical evaluation of CB1 receptors was also performed in the periaqueductal grey (PAG). Our results showed that the application of CB1-receptor agonist anandamide at the end of the stress led to a tendency of decrease in heat-SIA. We also found that each of the four Tyr-MIF-1 peptides interacted with the ECS after acute heat stress, resulting in changes in the PP-thresholds with different direction, degree, and duration. In particular, the administration of MIF-1 and Tyr-K-MIF-1 after CB1-receptor agonist anandamide increased heat stressinduced analgesia (heat-SIA) after the $10^{\text {th }}$ min, while Tyr-MIF-1 and Tyr-W-MIF-1 produced only short-lasting analgesia. CB1-expression in the PAG was also estimated, showing an increase after Tyr-MIF-1 and Tyr-W-MIF-1 administration with anandamide pretreatment, and a decrease after Tyr-W-MIF-1 administration with the CB1-receptor antagonist AM251-or the opioid receptor antagonist naloxone pretreatment. In summary, it can be inferred that under heat stress conditions the peptides from the Tyr-MIF-1 family, interacting with opioid and non-opioid receptors, differently relate with the cannabinoid system and such an interaction modulates heat stress-induced analgesia. It also seems that Tyr-MIF-1 and Tyr-W-MIF-1 have a direct impact on CB1-expression in the PAG, while MIF-1 and Tyr-K-MIF-1 probably act via second messengers or the activation of additional neurotransmitter system(s). Biomed Rev 2020; 31: 91-103

Keywords: stress-induced analgesia, endocannabinoid system, Tyr-MIF-1 peptides, Paw pressure test, immunohistochemistry

*Correspondence to: Dr Nikolai E. Lazarov, Department of Anatomy and Histology,

Medical University, 2 Zdrave Street, BG-1431 Sofia, Bulgaria

Tel: +359 29172 525; Fax: +359 28518 783; E-mail: nlazarov@medfac.mu-sofia.bg 


\section{INTRODUCTION}

Heat stress is among the most dramatic events in life with negative health consequences (1). The homeostatic regain following stress may cause damage to different organ systems. Understanding the mechanisms underlying stress and the possibilities to control them can reduce its harmful effects and prevent tissue and organ injury $(2,3)$.

It is known that under stressful conditions pain perception decreases, a phenomenon called stress-induced analgesia (SIA) (4). Stress induces the activation of several endogenous systems such as opioid, catecholaminergic, serotonergic, nitrergic, and endocannabinoid, and therefore both the opioid and non-opioid mechanisms are involved in the development of SIA $(5,6)$.

In the last years the endocannabinoid system (ECS) has received increasing research attention due to its implication in many physiological, such as emotion, memory, sleep, appetite, and metabolism, and pathological, for example pain and inflammation, processes. Moreover, it is implicated in the development of certain neurological and psychological disorders, and also in behavioral and alimentary disturbances $(7,8)$.

The ECS is a neuroactive lipid signaling system comprising two Gi/o-protein coupled receptors, CB1 and CB2 $(9,10,11)$, their endogenous ligands (endocannabinoids, eCBs), and the enzymes which either synthesize or degrade eCBs. The two best characterized eCBs are $\mathrm{N}$-arachidonoylethanolamide (anandamide, AEA) and 2-arachidonoylglycerol (12, 13). Immunohistochemical and quantitative in vitro autoradiographic studies confirm that CB1 is almost ubiquitously expressed in the nervous system, primarily in the brain, while CB2 is widely distributed in the immune and peripheral nervous systems (14-19). CB1 localization is predominantly presynaptic and it responds to eCBs that are synthesized 'on demand' in the postsynaptic neuron, thus signaling in a retrograde manner (20). Recent studies have shown that CB1 activation reduces nociceptive processing in acute and chronic animal pain models $(21,22)$. Thus, the ECS modulates the organism stress reaction, and SIA could be regarded as an indirect indicator of it.

The Tyr-MIF-1 family consists of four peptides: MIF-1 (Pro-Leu-Gly- $\mathrm{NH}_{2}$ ), Tyr-MIF-1 (Tyr-Pro-Leu-Gly- $\mathrm{NH}_{2}$ ), Tyr-W-MIF-1 (Tyr-Pro-Trp-Gly-NH 2 ), and Tyr-K-MIF-1 (TyrPro-Lys -Gly- $\mathrm{NH}_{2}$ ), all isolated from the human brain. The four peptides are implicated in pain perception. MIF-1 is the first peptide with confirmed anti-opiate effects with no affinity to opioid receptors, Tyr-K-MIF-1 binds to its own non-opioid receptors only, while the other two peptides possess both opioid and non-opioid binding sites (23).
Therefore, we set it as a goal of this study to evaluate the changes in heat stress-induced analgesia (h-SIA) after administration of exogenous agonists of CB1 receptors along with the peptides of the Tyr-MIF-1 family. Moreover, our aimed to estimate whether such changes were accentuated by any differences in CB1-expression in the periaqueductal gray (PAG), a region associated with both ECS and SIA in the rat brain $(6,24)$.

\section{MATERIALS AND METHODS}

\section{Animals, acute model of heat stress, drugs and treatment}

In vivo experiments were conducted on adult male Wistar rats, Rattus norvegicus, weighing $200 \pm 20$ g. The rats were kept at room temperature $\left(22 \pm 1^{\circ} \mathrm{C}\right)$, maintained under a $12 \mathrm{~h} / 12 \mathrm{~h}$ light/ dark regime, and supplied with standard chow and water ad libitum. The animals were divided into 16 groups $(\mathrm{n}=16)$, i.e. 15 experimental and one control. All experimental procedures were approved by the Research Ethics Commission of the Medical University of Sofia.

A heat stress model according to Wiley et al. (25) was applied. The animals were placed at high environmental temperature $\left(38^{\circ} \mathrm{C}\right)$ for 1 hour. During the time of heat exposure, the rats were allowed to move freely in the thermal chamber, although no food and water were provided.

All the drugs used in the study were purchased from Sigma (Sigma Chem. Co., St. Louis, MO, USA). CB1-receptor agonist AEA and CB1-receptor antagonist AM251 were injected intraperitoneally (i.p.) at a dose $1 \mathrm{mg} / \mathrm{kg}$ and $1.25 \mathrm{mg} / \mathrm{kg}$ b.w., respectively, dissolved in DMSO (25). The Tyr-MIF-1 peptides and the opioid receptor antagonist naloxone (Nal) were dissolved in sterile saline solution $(0.9 \% \mathrm{NaCl})$ and injected i.p. at a dose $1 \mathrm{mg} / \mathrm{kg}$ b.w.

\section{Experimental design}

For the in vivo experiments the animals from the $15 \mathrm{ex}-$ perimental groups were subjected to heat stress for one hour. AEA was injected immediately after the end of heat stress in five of the animal groups (No. $1-5$, Table 1). The peptides from the Tyr-MIF-1-family were administered 10 min after AEA injection in four experimental groups (No. $2-5$, Table 1): 1h HS+AEA+MIF-1; 1h HS+AEA+Tyr-MIF-1; $1 \mathrm{~h}$ HS+AEA+Tyr-W-MIF-1; 1h HS+AEA+Tyr-K-MIF-1. In other five groups (No. 6 - 10, Table 1) CB1-antagonist AM251 was applied immediately after the end of heat stress, followed by the administration of AEA alone or AEA and one of the four peptides (1h HS+AM251+AEA; 1h HS+AM251+AEA+MIF-1; 1 h HS+AM251+AEA+Tyr-MIF-1; 1h HS+AM251+AEA+Tyr-

Biomed Rev 31, 2020 
Table 1. Groups of experimental animals

\begin{tabular}{|c|c|c|}
\hline GROUP & ABBREVIATION & DESCRIPTION \\
\hline 1 & 1h HS+AEA & Heat stress for one hour followed by CB1-receptor agonist anandamide (AEA) \\
\hline 2 & 1h HS+AEA+MIF-1 & One hour of heat stress followed by AEA injection and MIF-1 application 10 min later \\
\hline 3 & 1h HS+AEA+Tyr-MIF-1 & $\begin{array}{l}\text { One hour of heat stress followed by AEA injection and Tyr-MIF-1 application } \\
10 \text { min later }\end{array}$ \\
\hline 4 & 1h HS+AEA+Tyr-W-MIF-1 & $\begin{array}{l}\text { One hour of heat stress followed by AEA injection and Tyr-W -MIF-1 application } \\
10 \text { min later }\end{array}$ \\
\hline 5 & 1h HS+AEA+Tyr-K-MIF-1 & $\begin{array}{l}\text { One hour of heat stress followed by AEA injection and Tyr-K -MIF-1 application } \\
10 \text { min later }\end{array}$ \\
\hline 6 & 1h HS+AM251+AEA & $\begin{array}{l}\text { One hour of heat stress followed by CB1-receptor antagonist AM251 injection and AEA } \\
\text { application } 10 \text { min later }\end{array}$ \\
\hline 7 & 1h HS+AM251+AEA+MIF-1 & $\begin{array}{l}\text { One hour of heat stress followed by AM251, AEA (10 min later), and MIF-1 application } \\
10 \text { min after AEA }\end{array}$ \\
\hline 8 & 1h HS+AM251+AEA+Tyr-MIF-1 & $\begin{array}{l}\text { One hour of heat stress followed by AM251, AEA (10 min later), and Tyr-MIF-1 } \\
\text { application } 10 \text { min after AEA }\end{array}$ \\
\hline 9 & 1h HS+AM251+AEA+Tyr-W-MIF-1 & $\begin{array}{l}\text { One hour of heat stress followed by AM251, AEA ( } 10 \text { min later), and Tyr-W-MIF-1 } \\
\text { application } 10 \text { min after AEA }\end{array}$ \\
\hline 10 & 1h HS+AM251+AEA+Tyr-K-MIF-1 & $\begin{array}{l}\text { One hour of heat stress followed by AM251, AEA (10 min later), and Tyr-K-MIF-1 } \\
\text { application } 10 \text { min after AEA }\end{array}$ \\
\hline 11 & 1h HS+Nal+AEA & $\begin{array}{l}\text { One hour of heat stress followed by application of opioid receptor antagonist naloxone } \\
\text { (Nal) and AEA } 20 \text { min later }\end{array}$ \\
\hline 12 & 1h HS+Nal+AEA+MIF-1 & One hour of heat stress followed by Nal, AEA ( 20 min later), and MIF-1 10 min after AEA \\
\hline 13 & 1h HS+Nal+AEA+Tyr-MIF-1 & $\begin{array}{l}\text { One hour of heat stress followed by Nal, AEA ( } 20 \text { min later), and Tyr-MIF-1 } 10 \text { min } \\
\text { after AEA }\end{array}$ \\
\hline 14 & 1h HS+Nal+AEA+Tyr-W-MIF-1 & $\begin{array}{l}\text { One hour of heat stress followed by Nal, AEA ( } 20 \text { min later), and Tyr-W-MIF-1 } 10 \text { min } \\
\text { after AEA }\end{array}$ \\
\hline 15 & 1h HS+Nal+AEA+Tyr-K-MIF-1 & $\begin{array}{l}\text { One hour of heat stress followed by Nal, AEA ( } 20 \text { min later), and Tyr-K-MIF-1 } 10 \text { min } \\
\text { after AEA }\end{array}$ \\
\hline
\end{tabular}

W-MIF-1; 1h HS+AM251+AEA+Tyr-K-MIF-1). The opioid receptor antagonist $\mathrm{Nal}$ was applied in the remaining five experimental groups (No. 11-15, Table 1) followed by the administration of AEA alone or AEA and one of the four peptides (1h HS+Nal+AEA; $1 \mathrm{~h} \mathrm{HS+Nal+AEA+MIF-1;} 1 \mathrm{~h}$ HS+Nal+AEA+Tyr-MIF-1; 1 h HS+Nal+AEA+Tyr-W-MIF-1; 1h HS+Nal+AEA+Tyr-K-MIF-1).

Assessment of the nociception began 10 min after the AEA/ peptide injection, and three evaluations were made with 10-min time interval between them (Figs. 1, 4-7).

\section{Nociceptive test}

Paw-pressure test (PP; Randall-Selitto test): The changes in the mechanical nociceptive thresholds of the rats were measured by an analgesimeter (Ugo Basile). In brief, pressure was applied to the rat hind-paw and the pressure (g) required for eliciting a nociceptive response, such as a squeak or struggle, was taken as the mechanical nociceptive threshold. A cut-off value of $500 \mathrm{~g}$ was observed to prevent damage of the paw.

\section{Immunohistochemistry, photodocumentation and image processing}

The immunohistochemical experiments were performed on the same animals used for the in vivo experiments; they were sacrificed immediately after the last in vivo evaluation. For 


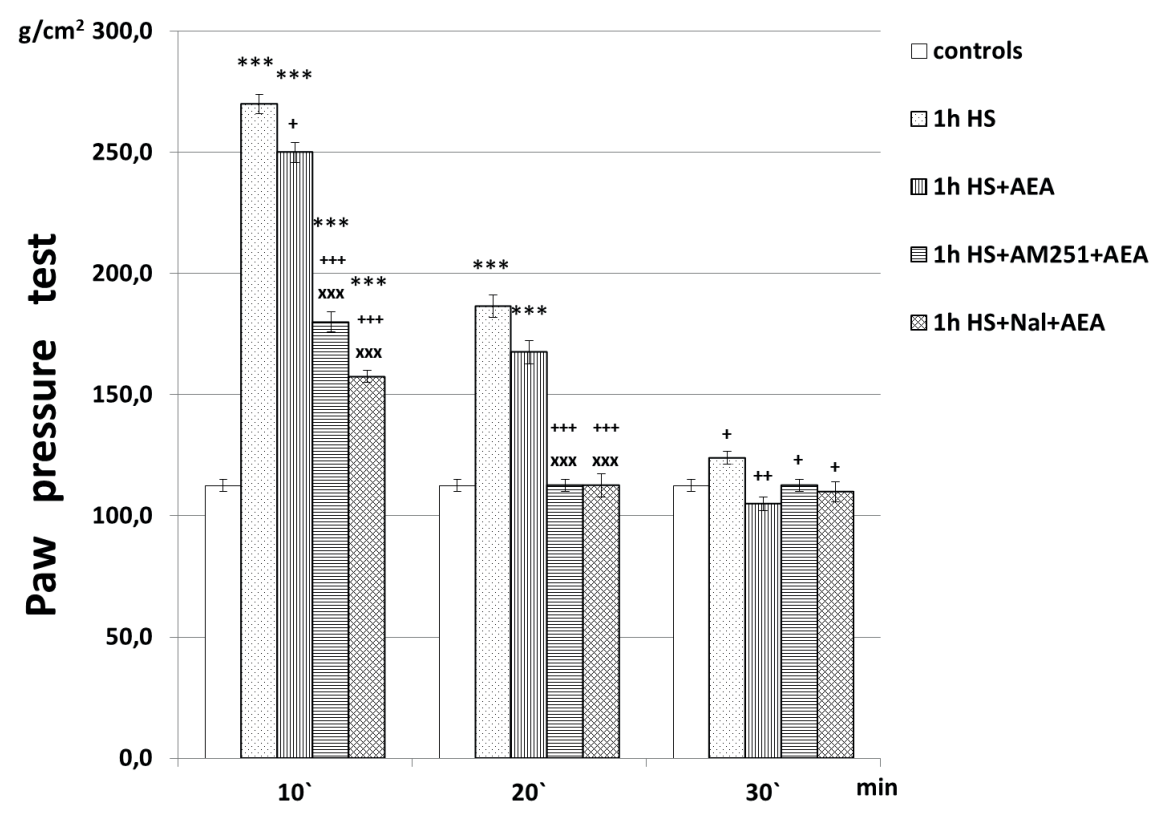

Figure 1. Heat-SIA modulation by anandamide (AEA) administration alone, and after AM251- and Nal-pretreatment. PP-thresholds are represented in $\mathrm{g} / \mathrm{cm}^{2}$; mean values \pm S.E.M. are presented. ${ }^{* * *} p<0.001$ vs. controls; ${ }^{++} p<0.001,{ }^{++} p<0.01,{ }^{+} p<0.05 v s .1 \mathrm{~h}$ $H S ;{ }^{x x} p<0.01,{ }^{x x x} p<0.001$ vs. 1 h $H S+A E A$.

the immunohistochemical experiments, the rats were deeply anesthetized and transcardially perfused first with $0.05 \mathrm{M}$ phosphate-buffered saline (PBS), pH 7.36, followed by 4\% paraformaldehyde (PFA) in $0.01 \mathrm{M}$ phosphate buffer (PB), $\mathrm{pH}$ 7.36. The brain was dissected out, sliced at the level of the midbrain and postfixed in the same fixative overnight at $4^{\circ} \mathrm{C}$. Thereafter, the tissues were embedded in paraffin and cut into $5 \mu \mathrm{m}$ thick sections. The samples were then deparaffinized with xylene and ethanol, and subsequently processed for avidin-biotin-horseradish peroxidase complex $(\mathrm{ABC})$ immunohistochemistry using an ImmunoCruz ${ }^{\mathrm{TM}}$ goat ABC Staining System (Santa Cruz Biotechnology, Inc., Santa Cruz, CA, USA). Briefly, the sections were treated with hydrogen peroxide (1\% in absolute methanol; $30 \mathrm{~min}$ ) to inactivate endogenous peroxidase and the background staining was blocked with $5 \%$ normal goat serum (NGS) in PBS for 1 hour. Between the separate steps, the sections were rinsed with cold PBS/Triton X-100. Afterwards, they were incubated for $24 \mathrm{~h}$ at room temperature with a polyclonal goat anti-CB1 receptor antibody (diluted 1:500, Santa Cruz Biotechnology) overnight at $4{ }^{\circ} \mathrm{C}$ in a humid chamber, followed by biotinylated donkey anti-goat IgG (Santa Cruz Biotechnology, 1:500) for $2 \mathrm{~h}$ at room temperature, and lastly the $\mathrm{AB}$ enzyme reagent was applied for $30 \mathrm{~min}$ at room temperature. Finally, the peroxidase activity was visualized by adding 1-3 drops of peroxidase substrate using diaminobenzidine as a chromogen. After the immunoreaction, the sections were dehydrated in ethanols, cleared in xylene and coverslipped with Entellan (Merck, Darmstadt, Germany). The slides were observed and photographed with a Nikon research microscope equipped with a digital camera DXM1200c. The brainstem structures were identified according to the rat brain atlas of Paxinos and Watson (26).

The specificity of the immunostaining was controlled by the omission of the primary antiserum from the incubation medium or its replacement with PBS. No immunoreactivity was detected in either case.

The immunostained sections for CB1 receptors were photographed, observed and examined in detail with a Nikon research microscope equipped with a DXM1200c digital camera and NIS-Elements imaging software. The system underwent an accurate calibration to correct the captured images. For every single image, the light source and camera settings were kept the same. Moreover, the settings for contrast and color were calibrated correctly. In particular, brightness and contrast were corrected for all images to prevent the strong influence of the contrast ratio on the original values of the pixels of a given image. The digital images were recorded in TIF format and processed for removal of artifacts using Adobe Photoshop CS5 software (Adobe Systems Inc., San Jose, CA). 


\section{Densitometric analysis and statistics}

CB1 staining intensity were quantified in binary-converted images using the semi-automated densitometrical evaluation after threshold settings via the open source program Image $1.48 \mathrm{v}$ (NIH, Bethesda, MD, USA). The results were presented as percentage areas after the relative staining intensities were semi-quantified. Two researchers (D.A. and A.D.) blinded to the experimental groups performed the assessments and the results were averaged.

Using the GraphPad Prism software package (GraphPad Software Inc., San Diego, CA, USA; version 5.04 for Windows) statistical analyses between groups were performed. The findings are presented as means \pm standard error of the mean (SEM). We applied unpaired $t$-test for Gaussian distributed data and Mann-Whitney $U$-test for non-Gaussian distributed data. The results were considered statistically significant when $\mathrm{p}<0.05$. The following symbols were used to indicate the different level of significance: ${ }^{*} \mathrm{p}<0.05,{ }^{* *} \mathrm{p}$ $<0.01$ and ${ }^{* * *} \mathrm{p}<0.001$.

\section{Data analysis}

In vivo results were statistically assessed by one-way analysis of variance (ANOVA) followed by Newman-Keuls post-hoc comparison test. Values were mean \pm S.E.M and these of $\mathrm{p}<0.05$ were considered to indicate statistical significance.

\section{RESULTS}

One hour of heat stress provoked heat stress-induced analgesia with PP-thresholds in experimental animals higher than those of the controls injected with $0.9 \%$ saline (Fig.1).

AEA-administration immediately after the end of stress led to a decrease in heat-SIA, even with minimal statistical relevancy between $1 \mathrm{~h}$ HS- and $1 \mathrm{~h}$ HS+AEA-group PP-thresholds. Instead, a relevant decrease in heat-SIA was observed after AM251-pretreatment, as well as after Nal-pretreatment (1h $\mathrm{HS}+\mathrm{Nal}+\mathrm{AEA}$ ) on the $10^{\text {th }}$ and $20^{\text {th }}$ min compared to $1 \mathrm{~h}$ HSand $1 \mathrm{~h} \mathrm{HS}+\mathrm{AEA}$-groups (Fig. 1).

The immunohistochemical experiments demonstrated staining for CB1 in some small-sized neurons located in the PAG. The cell bodies and proximal processes of these cells in ventrolateral periaqueductal gray (VLPAG) were differently immunostained in the examined experimental groups (Fig. 2). Specifically, following 1-hour heat exposure with AEA, many intensely stained neurons were observed in the VLPAG (Fig. 2A). Lower expression of CB1 receptors was seen in this area after both AM251 and Nal-pretreatment (Fig. 2C) compared to $1 \mathrm{~h} \mathrm{HS}+\mathrm{AEA}$ (Fig. 2A). Statistical data processing revealed that the ratio of neurons with CB1 receptor immunoreactivity was significantly higher statistically in the experimental group $1 \mathrm{~h} \mathrm{HS}+\mathrm{AEA}$ compared to groups $1 \mathrm{~h}$ HS+AM251+AEA (mean $74.10 \pm 4.434$ vs $52.702 \pm 4.232 ; \mathrm{p}=0.0036$ ) and $1 \mathrm{~h}$ HS+Nal+AEA (74.10 \pm 4.434 vs $43.83 \pm 3.155 ; \mathrm{p}=0.0001)$, respectively (Fig. 3).

MIF-1 administration (1h HS+AEA+MIF-1) on the $10^{\text {th }}$ min showed PP-thresholds lower than in the 1h HS- and the 1h HS+AEA-groups, while a continuous elevation of PPthresholds occurred after the $10^{\text {th }} \mathrm{min}$, with values on the $20^{\text {th }}$ and $30^{\text {th }}$ min higher than in $1 \mathrm{~h}$ HS- $\left(\mathrm{F}_{1,11}=418.97333\right.$ on the $20^{\text {th }}$ min; $\mathrm{F}_{1,11}=3472.05691$ on the $\left.30^{\text {th }} \mathrm{min}\right)$, and $1 \mathrm{~h}$ HS$+A E A-$ group $\left(F_{1,11}=689.64103\right.$ on the $20^{\text {th }}$ min; $F_{1,11}=4920.71685$ on the $30^{\text {th }}$ min) (Fig. 4). After AM251-pretreatment (1h HS+AM251+AEA+MIF-1) PP-thresholds gradually decreased after the $10^{\text {th }}$ min until the end of the experiments. Still, during the whole time of the evaluation they remained higher than the $1 \mathrm{~h}$ HS- $\left(\mathrm{F}_{1,11}=457.09717\right.$ on the $10^{\text {th }} \mathrm{min} ; \mathrm{F}_{1,11}=152.44444$ on the $20^{\text {th }} \mathrm{min} ; \mathrm{F}_{1,11}=65.68085$ on the $30^{\text {th }} \mathrm{min}$ ), and $1 \mathrm{~h}$ HS+AEA-values $\left(\mathrm{F}_{1,11}=822.85714\right.$ on the $10^{\text {th }} \mathrm{min}$; $\mathrm{F}_{1,11}=$ 345.02564 on the $20^{\text {th }}$ min; $F_{1,11}=240$ on the $30^{\text {th }} \mathrm{min}$ ) (Fig. 4).

Nal-administration decreased PP-thresholds in 1h HS+Nal+AEA+MIF-1-group compared to the $1 \mathrm{~h}$ HS+AEA+MIF-1-group $\left(\mathrm{F}_{1,11}=8.2963\right.$ on the $10^{\text {th }} \mathrm{min} ; \mathrm{F}_{1,11}=$ 841 on the $20^{\text {th }}$ min; $F_{1,11}=731.43137$ on the $30^{\text {th }} \mathrm{min}$ ) (Fig. 5).

Immunohistochemical data showed no statistically relevant change in CB1-expression in 1h HS+AEA+MIF-1-animals (Fig. 2D, 3) compared to the 1h HS+AEA group (Fig. 2A, 3) (60.038 \pm 4.854 vs $74.10 \pm 4.434 ; p=0.0932$ ), while both AM251(Fig. 2E and 3) and Nal- (Fig. 2F and 3) pretreatment before AEA+MIF-1-administration led to a decreased CB1-expression in groups $1 \mathrm{~h}$ HS+AM251+AEA+MIF-1 (43.866 \pm 2.554 vs 60.038 $\pm 4.854 ; \mathrm{p}=0.0111)$ and $1 \mathrm{~h} \mathrm{HS}+\mathrm{Nal}+\mathrm{AEA}+\mathrm{MIF}-1$ (29.860 \pm 2.781 vs $60.038 \pm 4.854 ; \mathrm{p}=0.0006)$ compared to $1 \mathrm{~h}$ HS+AEA+MIF-1-animals (Fig. 2D and 3), accordingly. Statistical analysis revealed that there were no significant differences in the expression of $\mathrm{CB} 1$ receptors when comparing groups 1h HS+AM251+AEA+MIF-1 and 1h HS+AM251+AEA (43.866 \pm 2.554 vs 52.702 \pm 4.232 ; $p=0.1504$ ) (Fig. 2E, $2 B$ and 3). Pretreatment with Nal- and the administration of the peptide MIF-1 caused a significant reduction of the expression of CB1 receptors in the experimental group $1 \mathrm{~h} \mathrm{HS}+\mathrm{Nal}+\mathrm{AEA}+\mathrm{MIF}-1$ (Fig. 2F) compared to the group $1 \mathrm{~h} \mathrm{HS}+\mathrm{Nal}+\mathrm{AEA}$ (Fig. 2C) (29.860 \pm 2.781 vs 43.825 \pm 3.155 ; p=0.0059) (Fig. 3).

Tyr-MIF-1-administration (1h HS+AEA+Tyr-MIF-1) 

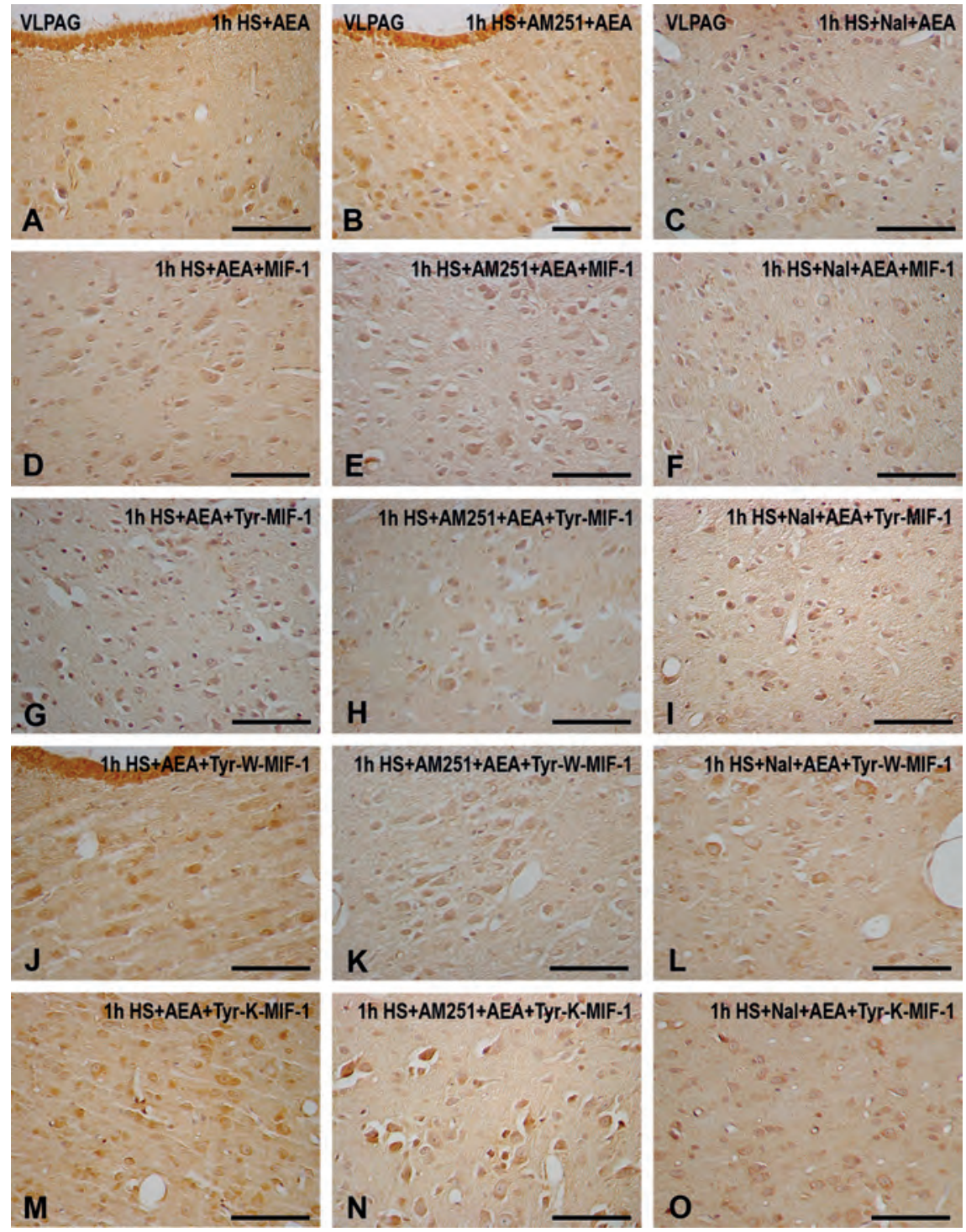

Figure 2. Immunohistochemical expression of CB1 receptors in some small-sized neurons located in the ventrolateral periaqueductal gray (VLPAG). The proximal processes and cell bodies of these cells are differently immunostained in the examined 15 experimental groups. Light photomicrographs in the left column $(\boldsymbol{A}, \boldsymbol{D}, \boldsymbol{G}, \mathbf{J}, \mathbf{M})$ show CB1 receptor immunoreactivity in five experimental groups in which the animals are subjected to 1-hour of heat stress followed by CB1-receptor agonist anandamide (AEA) (A) which serves as a control group. In the remaining four groups four different peptides from the Tyr-MIF-1 family are administered, i.e. MIF-1 (D), Tyr-MIF-1 (G), Tyr-W-MIF-1 (J) and Tyr-K-MIF-1 (M), respectively. Note that the administration of both Tyr-MIF-1 (G) and Tyr-W-MIF-1 (J) enhances the expression of CB1 receptors in the examined area while the peptides MIF-1 (D) and Tyr-K-MIF-1 (M) have no significant effect. The representative photomicrographs of the central column (B, E, $\boldsymbol{H}, \boldsymbol{K}, \boldsymbol{N})$ also include five experimental groups though in the animals from these groups, contrary to the left column, we use pretreatment with CB1-receptor antagonist AM251. (B) Pretreatment with AM251 reduces the expression of CB1 compared to the control group (A). Also note that both peptides Tyr-W-MIF-1 (K) and Tyr-K-MIF-1 (N) in groups with AM251-pretreatment significantly reduce the expression of CB1 receptors compared to the control group for the column $1 \mathrm{~h} H S+A M 251+A E A$ (B). The right column $(\boldsymbol{C}, \boldsymbol{F}, \boldsymbol{I}, \boldsymbol{L}, \boldsymbol{O})$ shows photomicrographs of five experimental groups of animals that are pretreated with the opioid receptor antagonist naloxone (Nal). (C) The CB1 immunopositive neurons in the VLPAG are more weakly immunostained compared to the control group (A). The administration of three peptides, i.e. MIF-1 (F), Tyr-MIF-1 (I) and Tyr-K-MIF-1 (O) in Nal-pretreated groups further reduces the expression of CB1 receptors. 


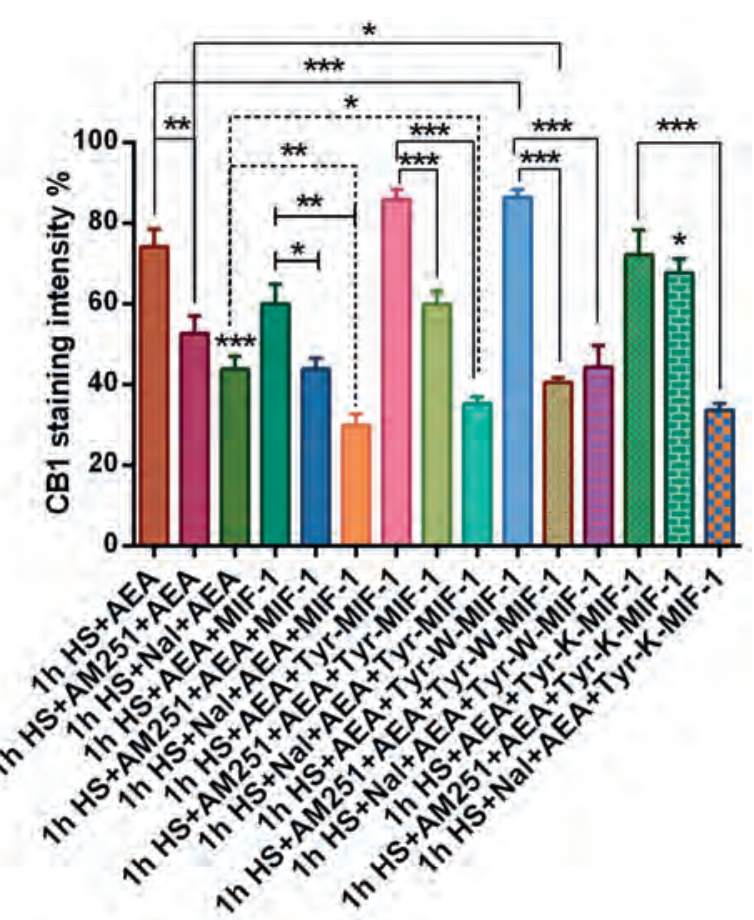

Figure 3. Densitometric analysis of anti-CB1 receptor staining intensity in the neurons of VLPAG in 15 experimental groups.

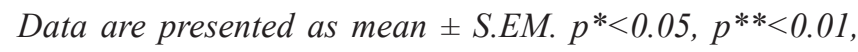
$p^{* * *<0.001 .}$ led to PP-thresholds higher than in the 1h HS+AEA-group $\left(F_{1,11}=74.07407\right)$ on the $10^{\text {th }} \mathrm{min}$. This increase was followed by a decrease on the $20^{\text {th }} \mathrm{min}$, while on the $30^{\text {th }}$ min the $1 \mathrm{~h}$ HS+AEA+Tyr-MIF-1-group PP-thresholds were comparable to the controls (Fig. 4). Administration of CB1-antagonist AM251 did not change PP-threshold curve compared to the agonist one (Fig. 4). Nal-pretreatment (1h HS+Nal+AEA+TyrMIF-1) increased PP-thresholds from the $20^{\text {th }}$ min on compared to $1 \mathrm{~h} \mathrm{HS}+\mathrm{AEA}$ and $1 \mathrm{~h}$ HS+AEA+Tyr-MIF-1 (Fig. 5).

The results of the statistical analysis showed increased CB1-expression in 1h HS+AEA+Tyr-MIF-1-animals (Fig. 2G, 3) compared to HS+AEA (Fig. 2A, 3) $(85.864 \pm 2.544$ vs 74.10 $\pm 4.434 ; \mathrm{p}=0.0410$ ). However, decreased CB1expression followed AM251- (Fig. 2H, 3) (59.825 \pm 3.166 vs 85.864 $\pm 2.544 ; \mathrm{p}<0.0001)$ and Nal- (Fig. 2I, 3) (35.302 \pm 1.734 vs $85.864 \pm 2.544 ; \mathrm{p}<0.0001)$ administration compared to $1 \mathrm{~h}$ HS+AEA+Tyr-MIF-1-animals (Fig. 2G, 3). Administration of the peptide Tyr-MIF-1 in animals pretreated with AM251 (1h HS+AM251+AEA+Tyr-MIF-1) did not statistically significant alter the expression of $\mathrm{CB} 1$ receptors compared to the non-peptide treated control group 1h HS+AM251+AEA (59.825 \pm 3.166 vs $52.702 \pm 4.232$; $\mathrm{p}=0.2008$ ) (Fig. $2 \mathrm{H}, 2 \mathrm{~B}$, 3). Whereas administration of the Tyr-MIF-1 peptide in the

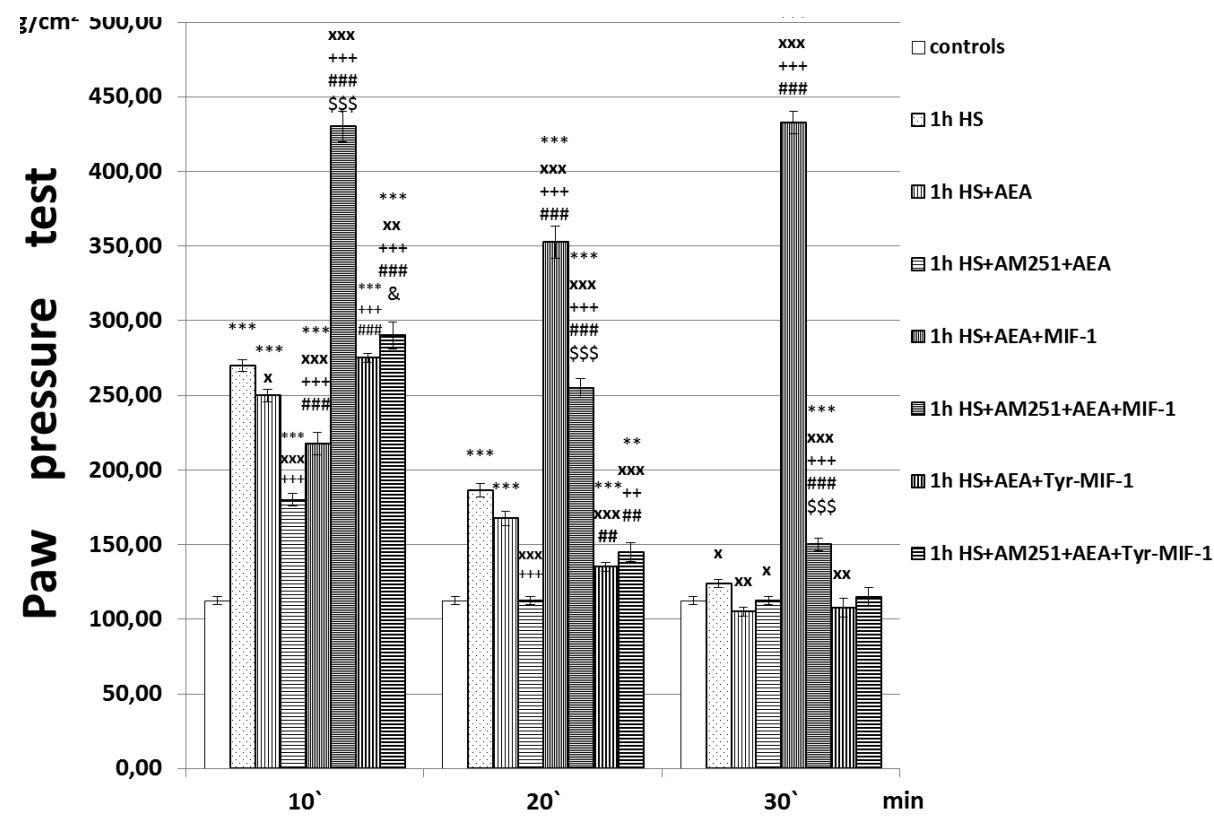

Figure 4. Effects of MIF-1 and Tyr-MIF-1 on SIA along with anandamide (AEA) administration and after CB1-antagonist AM251 pretreatment. PP-thresholds are represented in $\mathrm{g} / \mathrm{cm}^{2}$; mean values $\pm S . E . M$. are presented. ${ }^{* * *} p<0.001,{ }^{* *} p<0.01 v s$. controls; ${ }^{x x x} p<0.001,{ }^{x x} p<0.01,{ }^{x} p<0.05$ vs. $1 \mathrm{~h} \mathrm{HS} ;{ }^{+++} p<0.001$ vs. $1 \mathrm{~h} \mathrm{HS}+A E A$; ${ }^{* \#} p<0.001,{ }^{\#} p<0.01$ vs. $1 \mathrm{~h} \mathrm{HS}+A M 251+A E A$;

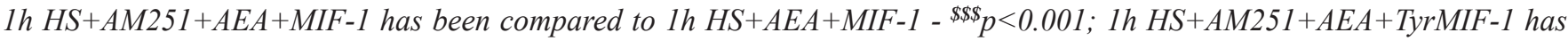
been compared to $1 \mathrm{~h} H S+A M 251+A E A+T y r-M I F-1-{ }^{*} p<0.05$. 


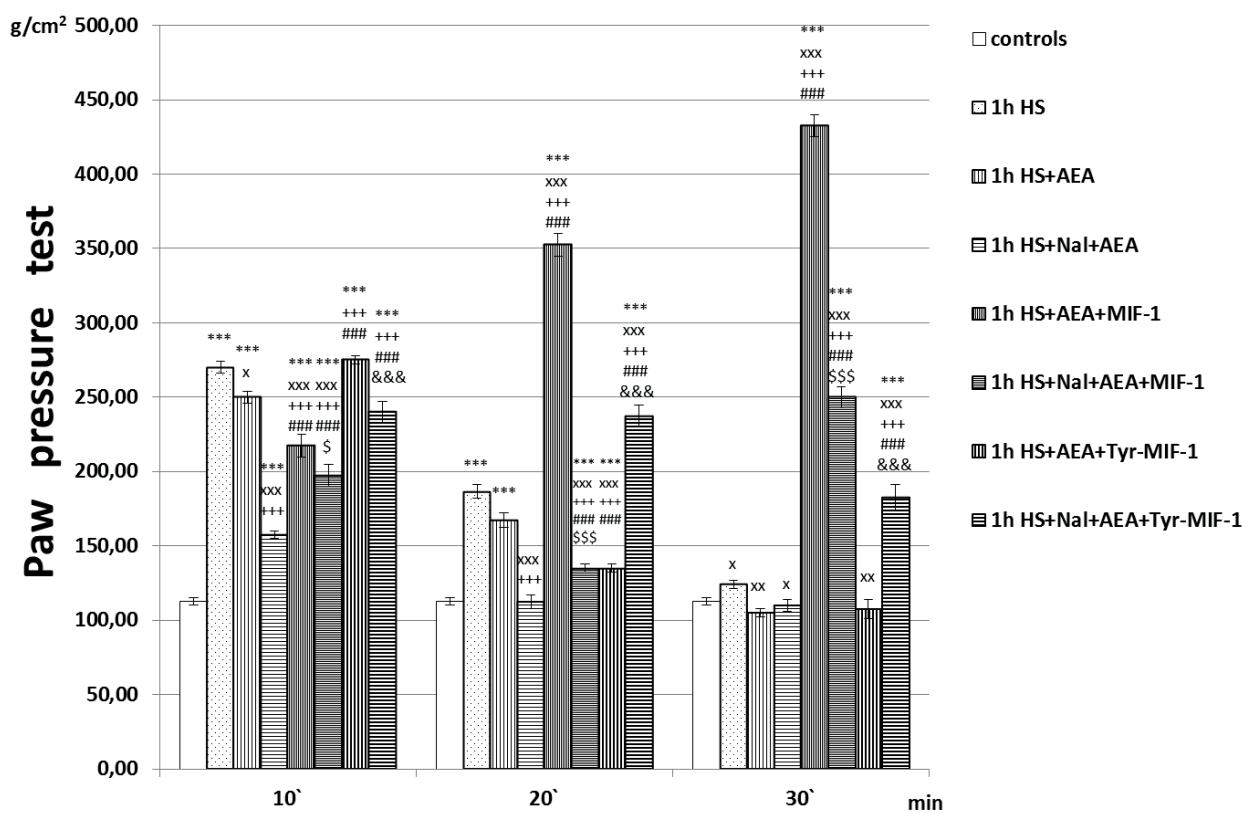

Figure 5. Effects of MIF-1 and Tyr-MIF-1 on SIA along with anandamide (AEA) administration and after opioid receptors antagonist naloxone (Nal) pretreatment. PP-thresholds are represented in $\mathrm{g} / \mathrm{cm}^{2} ;$ mean values \pm S.E.M. are presented. $* * * p<0.001$ vs. controls; ${ }^{x x x} p<0.001,{ }^{x x} p<0.01,{ }^{x} p<0.05$ vs. $1 \mathrm{~h} \mathrm{HS;}{ }^{+++} p<0.001$ vs. Ih HS+AEA; ${ }^{\circ \#} p<0.001$ vs. Ih HS+Nal+AEA; $1 \mathrm{~h}$ $H S+N a l+A E A+M I F-1$ has been compared to $1 \mathrm{~h} \mathrm{HS}+A E A+M I F-1-{ }_{-1 \$}{ }_{p}<0.001,{ }^{\$} p<0.05 ; 1 \mathrm{~h} \mathrm{HS}+\mathrm{Nal}+\mathrm{AEA}+\mathrm{Ty} r \mathrm{MIF}-1$ has been compared to $1 \mathrm{~h} H S+A E A+T y r-M I F-1$ - \&\&\& $p<0.001$.

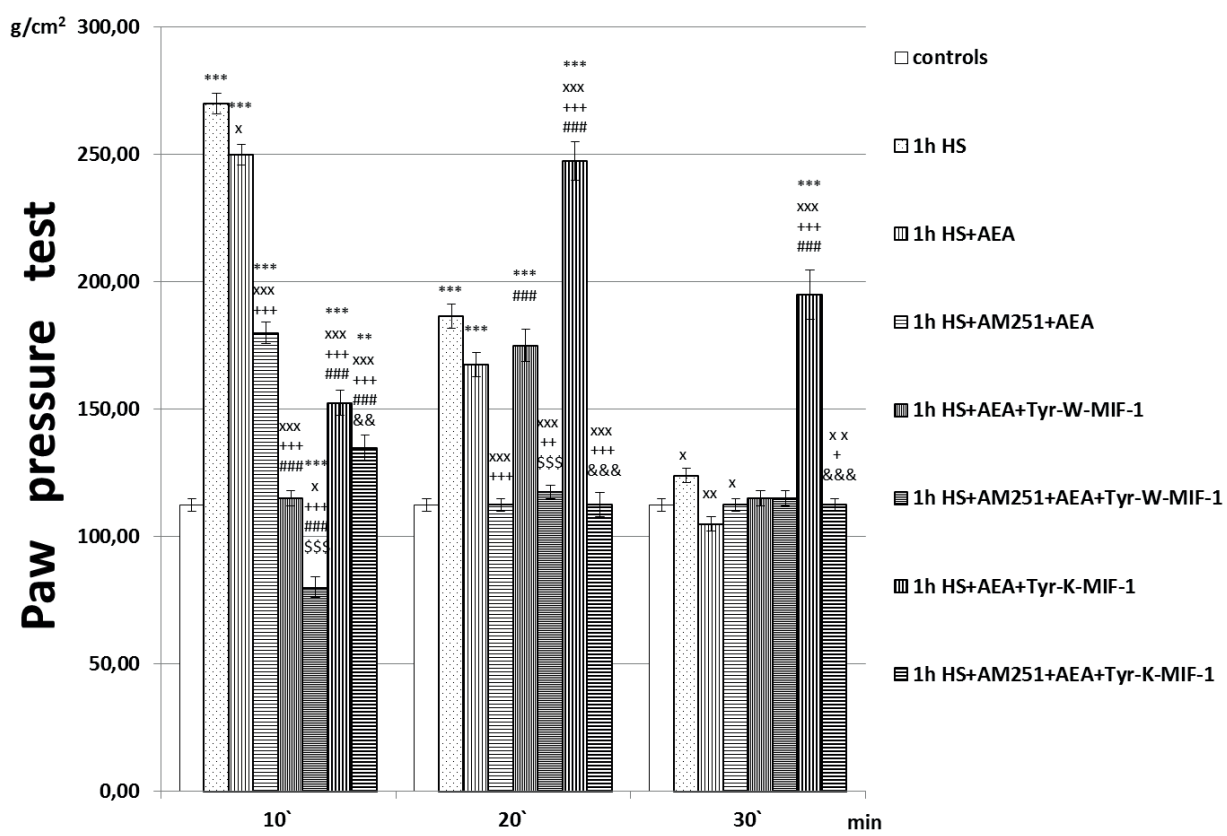

Figure 6. Effects of Tyr-W-MIF-1 and Tyr-K-MIF-1 on heat-SIA along with anandamide (AEA) administration and after CB1antagonist AM251 pretreatment. PP-thresholds are represented in $\mathrm{g} / \mathrm{cm}^{2}$; mean values \pm S.E.M. are presented. $* * * p<0.001$, ${ }^{* *} p<0.01$ vs. controls; ${ }^{x x x} p<0.001,{ }^{x x} p<0.01,{ }^{x} p<0.05 v s .1 \mathrm{~h} \mathrm{HS} ;{ }^{+++} p<0.001,{ }^{++} p<0.01,{ }^{+} p<0.05 v s .1 \mathrm{~h} \mathrm{HS}+A E A ;{ }^{*}{ }^{*} p<0.001$ vs. $1 \mathrm{~h} \mathrm{HS}+A M 251+A E A ; 1 \mathrm{~h} \mathrm{HS}+A M 251+A E A+T y r-W-M I F-1$ has been compared to $1 \mathrm{~h} H S+A E A+T y r-W-M I F-1$ - $\$ \$ \$ p<0.001 ; 1 \mathrm{~h}$ $H S+A M 251+A E A+T y r-K-M I F-1$ has been compared to $1 \mathrm{~h} H S+A E A+T y r-K-M I F-1$ - \&\&\& $p<0.001$, \&\& $p<0.01$. 
pretreated group with Nal (1h HS+Nal+AEA+Tyr-MIF-1) significantly reduces the expression of $\mathrm{CB} 1$ receptors compared to the control group1h HS+Nal+AEA $(35.302 \pm 1.734$ vs 43.825 \pm 3.155 ; $\mathrm{p}=0.0376$ ) (Fig. 2I, 2C, 3).

Tyr-W-MIF-1- and Tyr-K-MIF-1-administration led to inverted U-shaped PP-threshold curves, with higher values on the $20^{\text {th }}$ min compared to the $10^{\text {th }}$ and $30^{\text {th }}$ min after application. Tyr-W-MIF-1 caused analgesia only on the $20^{\text {th }}$ min of the experiment, but no statistically relevant difference than AEA was evaluated (Fig. 6). Tyr-K-MIF-1 led to a more prominent analgesic effect, with statistically relevant increase in heat-SIA on the $20^{\text {th }} \min \left(F_{1,11}=235.3089\right)$ and the $30^{\text {th }} \min \left(F_{1,11}=240\right)$ of the experiment compared to $1 \mathrm{~h}$ HS+AEA-values. No analgesic effects were observed for PP-thresholds after AM251administration (Fig. 6). Nal-pretreatment transiently increased PP-thresholds on the $10^{\text {th }}$ min in both $1 \mathrm{~h} \mathrm{HS}+\mathrm{Nal}+\mathrm{AEA}+\mathrm{Tyr}-$ W-MIF-1- and 1h HS+Nal+AEA+Tyr-K-MIF-1-animals compared to $1 \mathrm{~h}$ HS+AEA+Tyr-W-MIF-1- $\left(\mathrm{F}_{1,11}=224\right)$, and 1h HS+AEA+Tyr-K-MIF-1 groups $\left(F_{1,11}=62.36364\right)$, respectively. From the $20^{\text {th }}$ min on, $1 \mathrm{~h}$ HS+Nal+AEA+Tyr-W-MIF-1and $1 \mathrm{~h} \mathrm{HS}+\mathrm{Nal}+\mathrm{AEA}+\mathrm{Tyr}-\mathrm{K}-\mathrm{MIF}-1$-animals PP-thresholds were similar to the controls (Fig. 7). In comparison with the 1h HS+Nal+AEA-animals, 1h HS+Nal+AEA+Tyr-K-MIF1-group showed a statistically relevant increase for the entire time of the experiment $\left(F_{1,11}=72\right.$ on the $10^{\text {th }} \mathrm{min} ; \mathrm{F}_{1,11}=24.2$ on the $20^{\text {th }} \mathrm{min} ; \mathrm{F}_{1,11}=15.90909$ on the $30^{\text {th }} \mathrm{min}$ ), while for 1h HS+Nal+AEA+Tyr-W-MIF-1 statistical relevancy was evaluated only on the $20^{\text {th }} \min \left(\mathrm{F}_{1,11}=18\right)$.

Interestingly, we found that after a single dose of AEA followed by Tyr-W-MIF-1, the staining intensity of CB1immunoreactive neurons strongly increased in the VLPAG (Fig. 2J) compared to 1h HS+AEA (Fig. 2A) (86.251 \pm 2.106 vs $74.10 \pm 4.434 ; \mathrm{p}=0.0328$ ) (Fig. 3 ). Pretreatment with both AM251 (Fig. 2K, 3) $(40.473 \pm 1.268$ vs $86.251 \pm 2.106$; $\mathrm{p}<0.0001$ ) and $\mathrm{Nal}$ (Fig. 2L, 3) (44.402 \pm 5.187 vs 86.251 \pm 2.106 ; $\mathrm{p}<0.0001)$ decreased the CB1 receptor expression compared to 1h HS+AEA+Tyr-W-MIF-1-animals (Fig. 2J, 3). The staining intensity of $\mathrm{CB} 1$-immunoreactive neurons significantly reduced in the pretreated group with AM251 and Tyr-W-MIF-1 peptide administration (1h HS+AM215+AEA+Tyr-W-MIF-1) (Fig. 2K) compared to the control non-peptide treated group 1h HS+AM215+AEA $(40.473 \pm 1.268$ vs $52.702 \pm 4.232$; $\mathrm{p}=0.0237$ ) (Fig. 2B, 3). It is interesting to note that the impact of the peptide did not alter the expression of the CB1 receptors

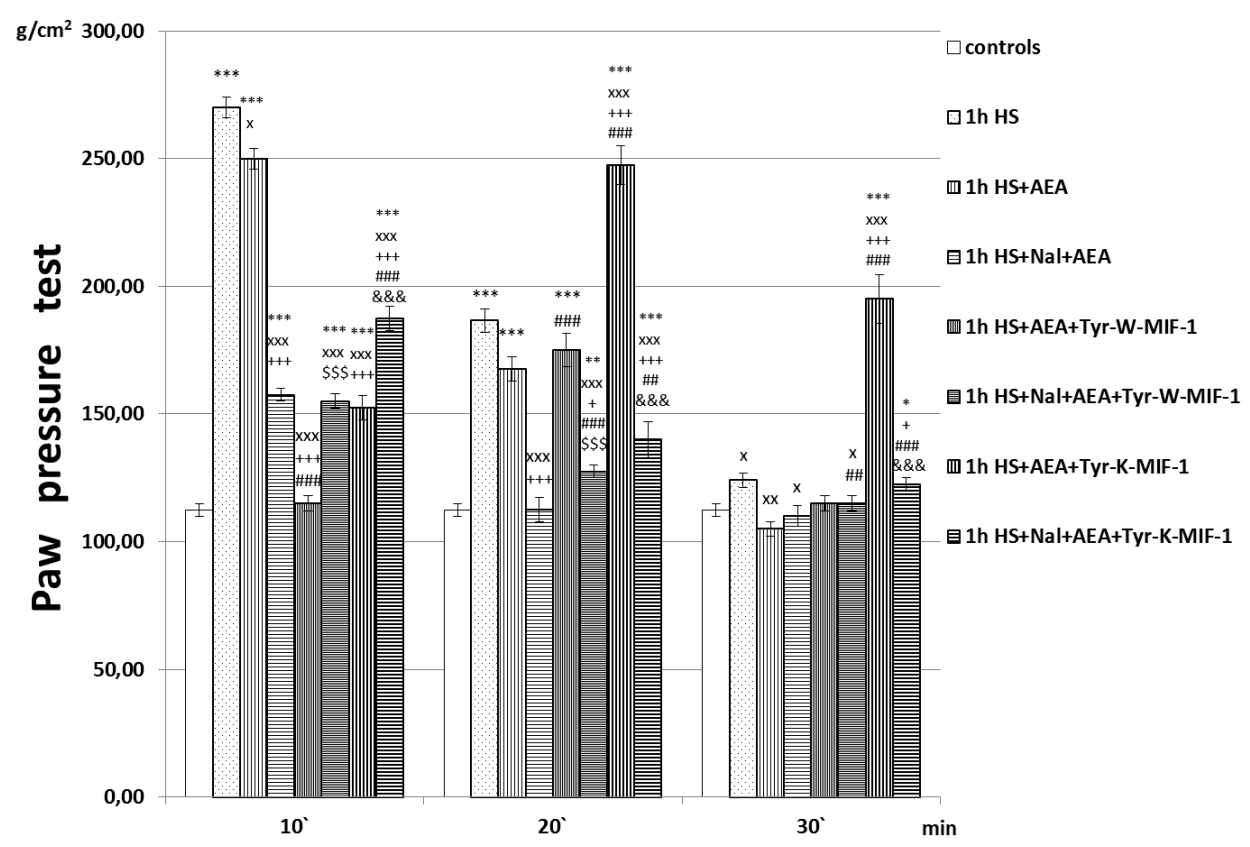

Figure 7. Effects of Tyr-W-MIF-1 and Tyr-K-MIF-1 on SIA along with anandamide (AEA) administration and after opioid receptors antagonist naloxone (Nal) pretreatment. PP-thresholds are represented in $\mathrm{g} / \mathrm{cm}^{2}$; mean values \pm S.E.M. are presented. ${ }^{* * *} p<0.001,{ }^{* *} p<0.01,{ }^{*} p<0.05$ vs. controls; ${ }^{x \times x} p<0.001,{ }^{x x} p<0.01,{ }^{x} p<0.05$ vs. $1 \mathrm{~h} \mathrm{HS} ;{ }^{+++} p<0.001,{ }^{+} p<0.05$ vs. $1 \mathrm{~h} \mathrm{HS}+A E A$;

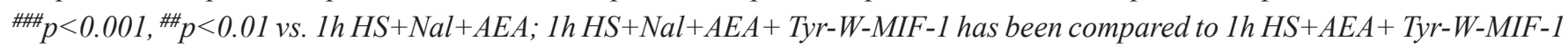
${ }_{-}{ }^{\$ \$}{ }_{p}<0.001 ; 1 \mathrm{~h} \mathrm{HS}+\mathrm{Nal}+A E A+T y r-K-M I F-1$ has been compared to $1 \mathrm{~h} H S+A E A+T y r-K-M I F-1-$ \&\&\& $p<0.001$ 
in the Nal- pretreated group $1 \mathrm{~h}$ HS+Nal+AEA+Tyr-W-MIF-1 (Fig. 2L) compared to the control group without peptide $1 \mathrm{~h}$ HS+Nal+AEA (44.402 \pm 5.187 vs $43.825 \pm 3.155$; $\mathrm{p}=0.9260)$ (Fig. 2C, 3).

Tyr-K-MIF-1-administration (1h HS+AEA+Tyr-KMIF-1, Fig. 2M, 3) did not change the level of CB1 receptor immunoreactivity compared to $1 \mathrm{~h} \mathrm{HS}+\mathrm{AEA}$ (Fig. 2A, 3) (72.126 \pm 6.172 versus $74.10 \pm 4.434$; $\mathrm{p}=0.7992)$. AM251pretreatment (1h HS+AM251+AEA+Tyr-K-MIF-1, Fig. 2N, 3) did not affect the CB1-expression either when compared to 1h HS+AEA+Tyr-K-MIF-1 (Fig. 2M, 3) (67.691 \pm 3.479 versus $72.126 \pm 6.172 ; \mathrm{p}=0.5441$ ), while Nal-pretreatment decreased the intensity of CB1-expression (Fig. 2O, 3) (33.625 \pm 1.625 versus $72.126 \pm 6.172$; $\mathrm{p}=0.0003$ ). Administration of Tyr-K-MIF-1 peptide in both pretreated groups with AM251- and Nal- altered the expression of CB1 receptors in a different way. In animals pretreated with AM251 (1h HS+AM251+AEA+Tyr-K-MIF-1) (Fig. 2N), the peptide enhanced the expression of $\mathrm{CB} 1$ receptors (72.126 \pm 6.172 versus 52.702 \pm 4.232; $\mathrm{p}=0.0165$ ) (Fig. 3), while in Nal-pretreated animals (1h HS+Nal+AEA+Tyr-K-MIF-1) (Fig. 2O) the TyrK-MIF-1 peptide decreased the expression of CB1 receptors (33.625 \pm 1.625 versus $43.825 \pm 3.155$; $\mathrm{p}=0.0159$ ) compared to their respective control groups $1 \mathrm{~h}$ HS+AM251+AEA and $1 \mathrm{~h}$ $\mathrm{HS}+\mathrm{Nal}+\mathrm{AEA}$.

\section{DISCUSSION}

The present results show that the peptides from the Tyr-MIF-1 family interact with the ECS, and such an interaction affects h-SIA. In particular, CB1 receptors, as well as opioid and other non-opioid receptors, take part in the final outcome of heat-SIA modulation. The administration of each peptide member of the family led to statistically relevant analgesia with a different onset, degree and duration depending on the peptide.

According to the extant literature both Tyr-MIF-1 and Tyr-W-MIF-1 bind to opioid receptors, the latter showing a higher binding affinity. Specifically, Tyr-MIF-1 has its own binding site $(23,27)$ whereas Tyr-W-MIF-1 interact with its own binding site even with a lower affinity $(23,28)$. Given their interaction with opioid receptors, Tyr-MIF-1 and TyrW-MIF-1 are expected to exert a prominent impact on heatSIA. Nonetheless, in this study only short-lasting analgesia is registered, i.e. on the $10^{\text {th }} \mathrm{min}$ in $1 \mathrm{~h} \mathrm{HS}+\mathrm{AEA}+\mathrm{Tyr}-\mathrm{MIF}-$ 1-animals compared to the $1 \mathrm{~h} \mathrm{HS+AEA-group} \mathrm{(fig.} \mathrm{4),} \mathrm{and}$ on the $20^{\text {th }}$ min for Tyr-W-MIF-1-animals (fig. 6). A probable explanation for this could be found in the antiopiate effect of these peptides albeit both of them have been proved to exert opiate effects as well (23).

Our results demonstrate that the administration of both peptides after AEA increases CB1-expression in PAG. Despite such an upregulated CB1-expression in $1 \mathrm{~h} \mathrm{HS+AEA+Tyr-}$ MIF-1-animals, the antiopiate effect of the peptide may antagonize the analgesic effect of cannabinoids in vivo. Moreover, Tyr-W-MIF-1-administration decreases CB1-expression after AM251-pretreatment, while Tyr-MIF-1 does not lead to statistically relevant differences in the expression. These findings can be attributed to the interactions between opioid and cannabinoid mechanisms in heat-SIA progress, as well as the involvement of the specific Tyr-MIF-1-binding site that Tyr-W-MIF-1 also binds.

There is available evidence that cannabinoid and opioid receptors are expressed in similar anatomical areas associated with analgesia, and are even colocalized in the same neurons (29- 31). In this regard, we find that CB1-expression in $1 \mathrm{~h}$ HS+Nal+AEA+Tyr-MIF-1-animals is decreased compared to 1 h HS+AEA+Tyr-MIF-1- but not in 1h HS+Nal+AEA-animals. We assume that the effect on CB1-expression can be attributed to naloxone that disrupts $\mathrm{CB} 1 /$ opioid receptor interactions. The antagonistic effect of naloxone on opioid receptors abolishes both the in vitro effect on CB1-expression through decreasing it and the in vivo effect via increasing analgesia. It is likely that by antagonizing the predominantly antiopiate effect of Tyr-MIF-1, Nal increases analgesia.

Further, we find a very distinct effect on heat-SIA following MIF-1 administration along with AEA: an increase in heat-SIA in the combination of AEA+MIF-1 (compared to the administration of AEA alone) is observed after the $10^{\text {th }}$ min until the end of the estimated time and exactly the opposite effect (a gradual decrease) after the CB1-antagonist application (Fig. 4). MIF-1 has its own binding sites, and a possible interaction with CB1 receptors can be suspected. Since immunohistochemical evaluation shows no statistically relevant changes in CB1-expression after MIF-1 administration (Fig. 2), the effect of the peptide could be attributed to implication of other receptors and potential second messengers.

Interestingly, even though the peptide is known not to interact with opioid receptors altogether, we register that Nal-administration decreases PP-thresholds in $1 \mathrm{~h} \mathrm{HS}+\mathrm{Nal}+\mathrm{AEA}+\mathrm{MIF}-1$-animals compared to $1 \mathrm{~h}$ HS+AEA+MIF-1- and 1h HS+Nal+AEA-groups (Fig. 5). Our immunohistochemical findings reveal a decreased CB1-expression after Nal-pretreatment (Fig. 2 and 3), thus 
indicating opioid receptor involvement as well as interactions between the peptide receptor and CB1 in heat-SIA progress. Our previous results show no similar in vivo effect in MIF-1 administration along with CB1-agonist after immobilization or cold stress (32, 33). Furthermore, Tyr-K-MIF-1 administration (1h HS+AEA+Tyr-K-MIF-1) leads to a PP-thresholds curve resembling an inverted U. The combination $1 \mathrm{~h} \mathrm{HS}+\mathrm{AEA}+\mathrm{Tyr}-$ K-MIF-1 provoked a delayed yet more pronounced and longlasting analgesic effect compared to 1h HS+AEA (Fig. 6). Since the combination 1h HS+AM251+AEA+Tyr-K-MIF-1 abolishes the above-mentioned analgesic effect of AEA and Tyr-K-MIF-1 on h-SIA, an interaction between CB1- and Tyr-K-MIF-1 receptors should be expected. Given that immunohistochemistry shows no statistically relevant changes in CB1-expression after the peptide application both with CB1-agonist or antagonist, common second messengers or the activation of additional mediatory systems may underlie such an assumption.

It is worth noting that the inverted U-shaped PP-threshold curve described above is also observed after immobilization and cold stress, only when the peptide is administered along with the CB1 antagonist AM251, and not after the application of the agonist $(32,33)$. In the present study the statistically relevant decrease, even after a transient increase on the $10^{\text {th }}$ min, in PP-thresholds observed from the $20^{\text {th }}$ min on in animals with $1 \mathrm{~h} \mathrm{HS}+\mathrm{Nal}+\mathrm{AEA}+\mathrm{Tyr}-\mathrm{K}-\mathrm{MIF}-1$ compared to $1 \mathrm{~h}$ HS+AEA+Tyr-K-MIF-1 groups (Fig. 7), was also characterized by a decreased CB1 expression (Fig. 2). Immunohistochemical data suggest that opioid and non-opioid receptors may influence ECS. Since Tyr-K-MIF-1 does not bind to opioid receptors, such an effect could be attributed to cannabinoid interactions with opioid mechanisms. It can be inferred that common second messengers for both cannabinoids and the peptide are implicated with the opioid system.

There is evidence that CB1 receptors, located at the presynaptic level, exert important control upon certain neuronal functions by modulating the release of several neurotransmitters (34). The presence of CB1 receptors in the rodent brain has been verified in certain glutamatergic, GABAergic, dopaminergic and adrenergic neurons (35), and recently in septohippocampal cholinergic (36) and raphal serotonergic neurons in mice (37). Our experiments were focused on PAG, traditionally associated with pain transmission in relation with opioids (38). Our results provide further immunohistochemical evidence that neurons in the rat PAG, which usually contain endogenous opioids and their receptors, possibly play impor- tant roles in pain modulation via activation of CB1 receptors, thus implying probable functional interactions between cannabinoids and opioids within the complex. It seems that the interaction between endocannabinoids and the peptides from Tyr-MIF-1 family influences SIA after cold, immobilization and heat stress, albeit in a different way. Obviously the activation of opioid and non-opioid receptors under various stress conditions leads to a certain extent to different interrelations with CB1 receptors.

It is known that there is considerable overlap in the pathways and neural substrates implicated in both pain and stress and that the activity within the descending pain pathway is a critical determinant of SIA (6). Moreover, a key regulator of descending pain pathway activity is the endogenous opioid system (39). Many drugs interact with endogenous receptors, opioid (e.g. $\mu$-receptors) and non-opioid (e.g. CB1 cannabinoid receptor and peptide receptors) and, therefore, we have tried to assess the analgesic effects of possible combinations between some of them. Furthermore, the involvement of other endogenous ligands for CB1, and the receptors AEA interacts with, should also be taken in consideration (40). Identifying certain patterns of interactions and creating models to influence the effects by activating/antagonizing given receptor(s), would provide novel perspectives in drug modelling.

\section{CONCLUSION}

Our study showed that the Tyr-MIF-1-family peptides interact with the ECS in hSIA modulation. Different degrees of analgesia with a variable duration are observed after the application of each of the four peptides. Tyr-MIF-1 and Tyr-WMIF-1 seem to have a direct impact on CB1-expression in the PAG, even with modest functional confirmation in the PP test, while MIF-1 and Tyr-K-MIF-1 probably interact via second messengers or additional neurotransmitter system activation.

\section{ACKNOWLEDGEMENTS}

This study was supported by a Grant № 27/2013 from the Medical Science Council of Medical University, Sofia, Bulgaria.

\section{DECLARATION OF COMPETING INTEREST}

The authors declare no potential conflict of interest.

\section{REFERENCES}

1. Gonzalez-Rivas PA, Chauhan SS, Ha M, Fegan N, Dunshea FR, Warner RD. Effects of heat stress on animal 
physiology, metabolism, and meat quality: A review. Meat Science 2020;162:108025. doi: 10.1016/j.meatsci.2019.108025.

2. Lupien SJ, McEwen BS, Gunnar MR, Heim C. Effects of stress through-out the lifespan on the brain, behavior and cognition. Nat Rev Neurosci 2009;10:434-445. doi: 10.1038/nrn2639.

3. Goldstein DS. Stress, allostatic load, catecholamines, and other neurotransmitters in neurodegenerative diseases. Endocr Regul 2011;45:91-98. doi: 10.1007/ s10571-011-9780-4.

4. Amit Z, Galina ZH. Stress-induced analgesia: adaptive pain suppression. Physiol Rev 1986;66:1091-1120. doi: 10.1152/physrev.1986.66.4.1091.

5. Hohmann AG, Suplita RL, Bolton NM, Neely MH, Fegley D, Mangieri R, et al. An endocannabinoid mechanism for stress-induced analgesia. Nature 2005;435:11081112. doi: 10.1038/nature03658.

6. Butler RK, Fin DP. Stress-induced analgesia. Prog Neurobiol 2009;88:184-202. doi: 10.1016/j.pneurobio.2009.04.003.

7. Mechoulam R, Parker LA. The endocannabinoid system and the brain. Annu Rev Psychol 2013;64:21-47. doi: 10.1146/annurev-psych-113011-143739.

8. Di Marzo V, Melck D, Bisogno T, De Petrocellis L. Endocannabinoids: endogenous cannabinoid receptor ligands with neuromodulatory action. Trends Neurosci 1998;21:521-528. doi: 10.1016/s0166-2236(98)01283-1.

9. Devane WA, Dysarz FA, Johnson MR, Melvin LS, Howlett AC. Determination and characterization of a cannabinoid receptor in rat brain. Mol Pharmacol 1988;34:605-613. PMID: 2848184.

10. Matsuda LA, Lolait SJ, Brownstein M, Young AC, Bonner TI. Structure of a cannabinoid receptor and functional expression of the cloned cDNA. Nature 1990;346:561564. doi: 10.1038/346561a0.

11. Munro S, Thomas KL, Abu-Shaar M. Molecular characterization of a peripheral receptor for cannabinoids. Nature 1993;365:61-65. doi: 10.1038/365061a0.

12. Devane WA, Hanus L, Breuer, A., Pertwee, RG, Stevenson LA, Griffin G, et al. Isolation and structure of a brain constituent that binds to the cannabinoid receptor. Science 1992;258:946-949. doi: 10.1126/science.1470919.

13. Sugiura T, Kondo S, Sukagawa A, Nakane S, Shinoda A, Itoh K, et al. 2-Arachidonoylglycerol: a possible en- dogenous cannabinoid receptor ligand in brain. Biochem Biophys Res Commun 1995;215:89-97. doi:10.1006/ bbrc.1995.2437.

14. Gong J-P, Onaivi ES, Ishiguro H, Liu Q-R, Tagliaferro PA, Brusco A, et al. Cannabinoid CB2 receptors: Immunohistochemical localization in rat brain. Brain Res 2006;1041:10-23. doi: 10.1016/j.brainres.2005.11.035.

15. Svíženská I, Dubový P, Šulcová A. Cannabinoid receptors 1 and 2 (CB1 and CB2), their distribution, ligands and functional involvement in nervous system structures - a short review. Pharmacol Biochem Behav 2008;90:501-511. doi:10.1016/j.pbb.2008.05.010.

16. Herkenham M, Lynn AB, Johnson MR, Melvin LS, de Costa BR, Rice KC. Characterization and localization of cannabinoid receptors in rat brain: a quantitative in vitro autoradiographic study. J Neurosci 1991;11:563-583. doi:10.1523/JNEUROSCI.11-02-00563.1991.

17. Mackie K. Distribution of cannabinoid receptors in the central and peripheral nervous system. In: Cannabinoids. Handbook of Experimental Pharmacology, Pertwee RG editor. Berlin Heidelberg: Springer; 2005; 299325. doi:10.1007/3-540-26573-2_10.

18. Mato S, Pazos A. Influence of age, postmortem delay and freezing storage period on cannabinoid receptor density and functionality in human brain. Neuropharmacology 2004; 46:716-726. doi:10.1016/j. neuropharm.2003.11.004.

19. Tsou K, Brown S, Sañudo-Peña MC, Mackie K, Walker JM. Immunohistochemical distribution of cannabinoid CB1 receptors in the rat central nervous system. Neuroscience 1998; 83:393-411. doi:10.1016/s03064522(97)00436-3.

20. Lovinger DM. Presynaptic modulation by endocannabinoids. In: Pharmacology of Neurotransmitter Release. Handbook of Experimental Pharmacology. Berlin, Heidelberg, Springer; 2008: 435-477. doi:10.1007/978-3540-74805-2_14.

21. Wilson RI, Nicoll RA. Endocannabinoid signaling in the brain. Science 2002; 296:678-682. doi:10.1126/science.1063545.

22. Starowicz K, Malek N, Przewlocka B. Cannabinoid receptors and pain. WIREs Membr Transp Signal 2013;2:121-132. doi:10.1002/wmts.83.

23. Pan W, Kastin AJ. From MIF-1 to endomorphin: The Tyr-MIF-1 family of peptides. Peptides 2007; 28:24112434. doi:10.1016/j.peptides.2007.10.006. 
24. Olango WM, Roche M, Ford GK, Harhen B, Finn DP. The endocannabinoid system in the rat dorsolateral periaqueductal grey mediates fear-conditioned analgesia and controls fear expression in the presence of nocicpetive tone. Br J Pharmacol 2012;165:2549-2560. doi: 10.1111/j.1476-5381.2011.01478.x.

25. Wiley JL, Walentiny MD, Wright Jr MJ, Beardsley PM, Burston JJ, Poklis JL, Lichtman AH, Vann RE. Endocannabinoid contribution to $\Delta$ 9-tetrahydrocannabinol discrimination in rodents. Eur J Pharmacol 2014;737:97105. doi:10.1016/j.ejphar.2014.05.013.

26. Paxinos $G$, Watson $C$. The rat brain in stereotaxic coordinates. Academic Press 1998; San Diego.

27. Zadina JE, Kastin AJ, Krieg Jr EF, Coy DH. Characterization of Binding Sites for N-Tyr-MIF-1 (Tyr-Pro-LeuGly-NH2) in Rat Brain. Pharmac Biochem \& Behav 1982;17:1193-1198. doi: 10.1016/0091-3057(82)90119-8.

28. Hackler L, Kastin AJ, Zadina JE. Isolation of a novel peptide with a unique binding profile from human brain cortex: Tyr-K-MIF-1 (Tyr-Pro-Lys-Gly-NH $\mathrm{N}_{2}$ ). Peptides 1994;15:945-950. doi:10.1016/0196-9781(94)90056-6.

29. Hohmann AG, Briley EM, Herkenham M. Pre- and postsynaptic distribution of cannabinoid and mu opioid receptors in rat spinal cord. Brain Res 1999;822:17-25. doi: 10.1016/s0006-8993(98)01321-3.

30. Welch SP, Stevens DL. Antinociceptive activity of intrathecally administered cannabinoids alone, and in combination with morphine in mice. J Pharmacol Exp Ther 1992; 262:10-18. PMID: 1320680.

31. Salio C, Fischer J, Franzoni MF, Mackie K, Kaneko T, Conrath M. CB1-cannabinoid and mu-opioid receptor co-localization on postsynaptic target in the rat dorsal horn. Neuroreport 2001;12:3689-3692. doi: 10.1097/00001756-200112040-00017.

32. Nocheva H, Kochev D, Bocheva A. Effects of Tyr-MIF1 family of peptides on endocannabinoid system after im- mobilization stress. C R Acad Bulg Sci 2013;66:10511056. doi: 10.7546/CR-2013-66-7-13101331-18.

33. Nocheva H, Kochev D, Krastev D, Bocheva A. Cold stress-induced analgesia. Interactions between the TYRMIF1 family of peptides and the endocannabinoid system. C R Acad Bulg Sci 2013;66:1639-1644.

34. Schlicker E, Kathmann M. Modulation of transmitter release via presynaptic cannabinoid receptors. Trends Pharmacol Sci 2001;22:565-572. doi:10.1016/s01656147(00)01805-8.

35. Kathmann M, Bauer U, Schlicker E, Göthert M. Cannabinoid CB1 receptor-mediated inhibition of NMDAand kainate-stimulated noradrenaline and dopamine release in the brain. Naunyn Schmiedebergs Arch Pharmacol 1999;359:466-470. doi: 0.1007/PL00005377.

36. Nyiri G, Szabadits E, Cserep C, Mackie K, Shigemoto $\mathrm{R}$, Freund TF. GABAB and CB1 cannabinoid receptor expression identifies two types of septal cholinergic neurons. Eur J Neurosci 2005; 21:3034-3042. doi:10.1111/ j.1460-9568.2005.04146.x.

37. Häring M, Marsicano G, Lutz B, Monory K. Identification of the cannabinoid receptor type 1 in serotonergic cells of raphe nuclei in mice. Neuroscience 2007;146:12121219. doi:10.1016/j.neuroscience.2007.02.021.

38. Wilson-Poe AR, Morgan MM, Aicher SA, Hegarty DM. Distribution of CB1 cannabinoid receptors and their relationship with mu-opioid receptors in the rat periaqueductal gray. Neuroscience 2012; 213:191-200. doi:10.1016/j.neuroscience.2012.03.038.

39. Ferdousi M, Finn DP. Stress-induced modulation of pain: Role of the endogenous opioid system. Prog Brain Res 2018;239:121-177. doi: 10.1016/bs.pbr.2018.07.002.

40. Di Marzo V, De Petrocellis L. Why do cannabinoid receptors have more than one endogenous ligand? Phil Trans $R$ Soc B 2012;367:3216-3228. doi:10.1098/ rstb.2011.0382. 